\section{The gap between knowledge on HIV/AIDS and sexual behavior: a study of teenagers in Vespasiano, Minas Gerais State, Brazil}

\author{
A lacuna entre o conhecimento sobre HIV/AIDS e \\ o comportamento sexual: uma investigação com \\ adolescentes de Vespasiano, Minas Gerais, Brasil \\ La laguna entre el conocimiento sobre VIH/SIDA y \\ el comportamiento sexual: una investigación con \\ adolescentes de Vespasiano, Minas Gerais, Brasil
}

Luciana Ramos de Moura 1,2 Joyce Romano Lamounier 2 Patrícia Regina Guimarães 2 Júlia Mesquita Duarte 2 Maria Tereza Cordeiro Beling ${ }^{2}$ Jorge Andrade Pinto 2

Eugênio Marcos de Andrade Goulart 2 Cristiane de Freitas Cunha Grillo 2

\title{
Resumo
}

${ }^{1}$ Faculdade de Ciências Médicas de Minas Gerais, Belo Horizonte, Brasil. 2 Faculdade de Medicina, Universidade Federal de Minas Gerais, Belo Horizonte, Brasil.

Correspondence L. R. Moura

Faculdade de Medicina, Universidade Federal de Minas Gerais. Av. Alfredo Balena 190, Belo Horizonte, $M C$ 30130-100, Brasil.

lulysramos29@yahoo.com.br

\section{Abstract}

The aim of this study was to investigate gaps between knowledge on HIVIAIDS and sexual behavior among teenagers. The study used a cross-sectional design with a representative random sample of 1,158 teenagers (14 to 19 years of age) enrolled in nine public secondary schools and who answered validated questionnaires. Data analysis included descriptive statistics and tests of hypotheses (chi-square, Mann-Whitney and Kruskal-Wallis, Kendall, and Fisher's exact test). The vast majority of the teenagers (98.7\%) expressed doubt on at least one question. Condom use during first sexual intercourse was significantly associated with condom use in sexual relations in the previous six months. There was no statistical association between knowledge on HIVIAIDS and frequency of condom use or number of sexual partners. Health actions are needed that link schools to health services, in addition to not only elaborating appropriate information but also valorizing teenagers' individuality in the development of proposals

HIV; Acquired Immunodeficiency Syndrome; Adolescent; Health Knowledge, Attitudes, Practice; Sexual Behavior
O objetivo foi investigar as lacunas entre o conhecimento sobre o HIVIAIDS e o comportamento sexual em adolescentes do ensino médio. Delineamento transversal com amostra representativa e aleatória de 1.158 adolescentes entre 14 a 19 anos, matriculados em nove escolas públicas que responderam a questionários validados. A análise dos dados envolveu estatística descritiva e testes de hipóteses (qui-quadrado, Mann-Whitney e Kruskal-Wallis, Kendal e teste exato de Fisher). A maioria dos adolescentes (98,7\%) apresentou dúvida em alguma questão proposta. O uso do preservativo na primeira relação sexual influenciou o uso nas relações dos últimos seis meses. Não houve associação estatística entre o conhecimento sobre HIVIAIDS com a frequência do uso de preservativo e a multiplicidade de parceiros sexuais. É necessário a implementação de ações em saúde que articulem a escola aos serviços de saúde e que além de trabalhar a informação, valorizem a individualidade dos adolescentes na construção das propostas.

HIV; Síndrome de Imunodeficiência Adquirida; Adolescente; Conhecimentos, Atitudes e Prática em Saúde; Comportamento Sexual 


\section{Introduction}

Young people have been identified in the international literature as an important group in terms of epidemiological risk of sexually transmitted diseases (STD) and are a priority in prevention campaigns promoted by the United Nations 1,2 . In this scenario, knowledge becomes a key component for reducing high-risk behavior by allowing individuals to review their practices. However, studies have shown that knowledge alone is insufficient to promote safe sexual behavior. Among groups of adolescents with different levels of information on HIV/AIDS, those with the most knowledge do not necessarily protect themselves from infection 3,4 .

Condom use is widely recommended as a way of avoiding sexually transmitted diseases and involves both moral values and affective and sexual issues 5,6. According to Camargo et al. 7, knowledge on HIV/AIDS does not always relate to the adoption of preventive behavior, and publicizing information on the disease does not necessarily lead to changes in habits. According to the same principle, Ferreira ${ }^{8}$ states that although the degree of information on HIV transmission alone is insufficient for a person to adopt protective behavior, the lack of basic information contributes substantially to increasing vulnerability to the epidemic.

The construction of knowledge on HIV/AIDS is not limited to information, but also involves individual perception of the problem, cultural values, and behavioral models dictated by society. The power of knowledge in behavior change thus depends on issues that transcend technical information 9 . The transformation of knowledge into safe practices is therefore mediated by gender, schooling, social class, and cultural issues, among others. From this perspective, Ayres \& Fontes 10 state that behavior change depends not only on individual will, but also on social factors that affect understanding of the questions and thus changes in attitude.

According to current data from the Brazilian Ministry of Health, although HIV/AIDS incidence has decreased in the general population, it has increased among young people: in five years, the prevalence of HIV infection in this age group has increased from $0.09 \%$ to $0.12 \% 11$. The Brazilian Population Survey on Sexual Behavior and Perceptions Towards HIVIAIDS (PCAP 2008) shows that the 13-19-year age bracket is the only one in which there are more cases of the disease in females 11. This gender reversal has been observed since 1998, with eight cases in boys for every 10 cases in girls.
Preventive action in different countries is hindered by the fact that public policies fail to take the populations' sexual culture into account 12 . National characteristics should be considered in the development of educational campaigns and actions. Thus, although the HIV/AIDS epidemic has a worldwide scope and repercussions, the adaptation of campaigns to a country's epidemiological, cultural, social, and economic context allows a closer approach to the reality in the field. In Brazil, the country's demographic and epidemiological heterogeneity implies sub-epidemics 13 . In the midst of such diversity, national studies that approach regional specificities are still scarce. According to the Brazilian Ministry of Health, studies evaluating HIV/AIDS issues should be constantly updated and conducted with a regionalized approach, thus contributing to the development of proposals that are more attuned to specific social, economic, and cultural contexts 14 .

The current study aimed to investigate HIV/ AIDS-related knowledge, sexual behavior, and their correlation among adolescents. The study was conducted in public schools in the city of Vespasiano in Greater Metropolitan Belo Horizonte, capital of Minas Gerais State, Brazil. The city is paradigmatic due to the high prevalence of poverty and violence and the high teen pregnancy rate, one of the highest in Minas Gerais (Departamento de Informática do SUS. Sistema de Informações sobre Nascidos Vivos. http://www. datasus.gov.br/catalogo/sinasc.htm, accessed on 20/Nov/2010). The issues described above justify the choice of the city for the current study, since risk behaviors for teen pregnancy are similar to factors favoring HIV infection. Prevalence of the epidemic in Brazil, its epidemiological repercussions, and the vulnerability of teenagers to the virus justify the proposed theme.

\section{Method}

The original sample population included 3,654 teenagers 14 to 19 years of age enrolled in public schools in Vespasiano in 2010. Statistical calculation used stratified sampling to estimate the sample. The schools were the strata, and their distribution in Vespasiano covers different social strata. The target variable was the proportion of an expected level of knowledge of 0.57215 , and the final sample was 812 , considering an alpha error $\pm 0.03=0.0516$. Predicting a $40 \%$ loss rate, the decision was made to invite approximately 1,137 subjects 14 to 19 years of age with random distribution by gender. 
All nine public schools offering secondary schooling in the municipality of Vespasiano participated in the study. Classes within each school were selected randomly. To maintain representativeness, the number of participants was proportional to the number of students enrolled in each school. All the students from the selected classes were invited to participate.

Participants answered the questionnaires anonymously: Questionnaire for the Evaluation of Knowledge on HIVIAIDS (QAC) and Questionnaire for the Evaluation of High-Risk Sexual Behavior (QACSR). The Brazilian Economic Classification Criterion was the instrument chosen to evaluate subjects' economic class (Associação Brasileira de Empresas de Pesquisa. http://www. abep.org, accessed on 04/Jan/2011).

Knowledge on HIV transmission and AIDS was assessed with the questionnaire from the PCAP 2008 17. The questionnaire consists of nine multiple-choice questions divided into two groups. The first group, entitled "Forms of Transmission", includes six questions on transmission of the virus by social contact, condom use as a form of preventing HIV infection, oral sex, coitus interruptus, and sharing needles and syringes. The second group of questions, entitled "Risk Situations", has three questions assessing the individual's knowledge on risk of infection in heterosexual couples with stable partners, homosexual couples with stable partners, and individuals with multiple sexual partners. For each question, respondents were classified as "well informed" or "poorly informed"; dichotomous classification aimed to simplify assessment of knowledge on HIV/AIDS. The sum of the two groups of questions comprised the General Indicator of Knowledge on HIV/AIDS, consisting of nine questions.

The instrument for evaluation of high-risk sexual behavior (QACSR) contains 28 questions. Of these, six relate to predisposing factors for high-risk sexual behavior, for example, age at first sexual intercourse. Eleven other questions relate to risk versus preventive behaviors per se, such as condom use. The other questions approach general themes such as sources of information on sex/sexuality. We opted to use the "six months" cutoff point for individuals' recall of their sexual behavior. Despite the lack of consensus on this issue in the literature, similar studies use the same cutoff 18,19 .

The following cutoff points were set for the teenage age bracket: $14-15$ years, $16-17$ years, and 18-19 years. This division corresponds to three phases described in the literature: early adolescence, from 10 to 14 years; mid-adolescence, from 14 to 16 years; and late adolescence, from 17 to 20 years 20 .
In each school, the questionnaires were all applied on a single day at the same time in various classrooms. The research team ensured that the teenagers did not exchange information on the questionnaires, and one researcher stayed in the classroom while the questionnaire was being answered. On average, students took 30 minutes to answer the three questionnaires.

The results of a pilot study in a similar sample in a State public school in the city of Belo Horizonte demonstrated the adequacy of the study method and instruments for teenagers enrolled in secondary school.

The study procedures complied with the guidelines of the National Board of Research Ethics (CONEP). The research project was approved by the Institutional Review Board of the Minas Gerais Federal University (COEP/UFMG) and was authorized by the schools' administrators, parents or guardians, and the teenagers themselves. The teenagers signed a free and informed consent form authorizing their inclusion in the study. According to Ruling 196 of the Brazilian National Health Council, participation by teenagers less than 18 years of age requires their parents' or guardians' signature, in addition to their own. Researchers made prior contact with the classes to distribute the informed consent forms. The study excluded teenagers that refused to participate, failed to present the properly signed consent form, or were not present in the classroom when the questionnaires were distributed.

Data were analyzed with EpiInfo 6.04 (Centers for Disease Control and Prevention, Atlanta, USA) and SPSS version 15.0 (SPSS Inc., Chicago, USA). Statistical significance was set at $5 \%(\alpha=$ 0.05 ) for all the analyses. The descriptive statistical measures were means, standard deviation, medians, and range. According to the Kolmogorov-Smirnov test, used to test the hypothesis that two data distributions are normal, the age variable and the three indices of knowledge on HIV/ AIDS did not display normal distribution. Thus, non-parametric statistical tests were used in all the analyses. Relationships between the variables were established with contingency tables (chisquare test) and the Fisher's exact test when necessary (expected value of a box smaller than five). The Mann-Whitney test was used to compare two different conditions and the Kruskal-Wallis test for cases in which there were more than two conditions. The Kendall correlation was used to verify the association between categorical and continuous variables.

An association was measured between the General Indicator of Knowledge on HIV/AIDS and high-risk sexual practices according to the literature: lack of condom use and multiple sexu- 
al partners 17,21,22,23,24, the latter two evaluated by the questionnaire on high-risk sexual behavior.

\section{Results}

The study sample consisted of 1,158 teenagers enrolled in the first, second, and third years of secondary school (morning, afternoon, and evening shifts), with a predominance of girls (57.4\%). Mean age was 16.4 years $(\mathrm{SD}=1.2)$ and the majority belonged to economic class $\mathrm{C}$, or a mean monthly income of US\$ 417.00. Mean age at first sexual intercourse was 14.8 years $(\mathrm{SD}=1.5)$. On average, sexual initiation for male teenagers was six months earlier than for females: 14.5 years $(\mathrm{SD}=1.6)$ for boys and 15.1 years $(\mathrm{SD}=1.2)$ for girls; according to the Mann-Whitney test, this difference is significant $(p<0.001)$. At the time of the study, $60.1 \%$ of the boys were already sexually initiated, as compared to $40.5 \%$ of the girls ( $\mathrm{p}<$ 0.001). Table 1 shows the results.

The results showed a median of 5 points (range $=0-9$ ) for the General Indicator of Knowledge, showing that the teenagers answered five of the nine questions most of the time. Evaluated separately, the groups of questions showed the following median numbers of correct answers: 1 point (range $=0-3$ ) out of a total of three questions for the group of Risk Situations, and 4 points ( $\mathrm{SD}=0-6)$ out of a total of six questions for forms of transmission.

Interestingly, only $1.3 \%$ of the teens reached a maximum score on the scale of knowledge, which would demonstrate being well-informed on HIV/ AIDS. This situation shows that nearly all of the individuals in the sample (98.7\%) were in doubt on least one question related to HIV/AIDS. Figure 1 shows the distribution of the General Indicator of Knowledge, considering all nine questions, for this group of teenagers in Vespasiano.

As for condom use during first sexual intercourse, there were no statistically significant differences between boys and girls. However, during the six months prior to the study, boys showed a higher rate of condom use. In generally, condom use was higher among younger boys and girls (14 to 15 years old). There were no differences in condom use between different economic classes (Table 2).

In order to evaluate a potential correlation between condom use at first sexual intercourse

\section{Table 1}

Age at sexual initiation according to gender, grade in school, age, and economic class among a sample of teenagers in Vespasiano, Minas Gerais State, Brazil, 2010

\begin{tabular}{|c|c|c|c|c|c|c|c|c|}
\hline \multirow[t]{2}{*}{ Variable } & \multirow[t]{2}{*}{$\mathbf{N}$} & \multirow[t]{2}{*}{$\%$} & \multicolumn{3}{|c|}{$\begin{array}{l}\text { Already had sexual intercourse? } \\
\qquad \mathrm{n}(\%)\end{array}$} & \multicolumn{3}{|c|}{ Age at sexual initiation } \\
\hline & & & Yes & No & $\mathrm{p}$-value * & Median & Range & p-value \\
\hline \multicolumn{9}{|l|}{ Gender } \\
\hline Male & 489 & 42.6 & $297(60.1)$ & 197 (39.9) & $<0.001$ & 15 & $9-18$ & $<0.001$ ** \\
\hline Female & 657 & 57.4 & $267(40.5)$ & $393(59.5)$ & & 15 & $11-18$ & \\
\hline \multicolumn{9}{|l|}{ Grade } \\
\hline $1 \mathrm{st}$ & 425 & 36.7 & $200(47.1)$ & $225(52.9)$ & 0.28 & 14 & $9-18$ & $<0.001 * * *$ \\
\hline $2^{\text {nd }}$ & 404 & 34.9 & $193(47.8)$ & $221(52.2)$ & & 15 & $9-20$ & \\
\hline 3 rd & 329 & 28.4 & $173(52.6)$ & $156(47.4)$ & & 15 & $10-18$ & \\
\hline \multicolumn{9}{|l|}{ Age (years) } \\
\hline $14-15$ & 250 & 21.9 & 78 (31.2) & $172(68.8)$ & $<0.001$ & 14 & $10-16$ & $<0.001 * \star \star$ \\
\hline $16-17$ & 686 & 59.9 & $343(50.0)$ & $344(50.0)$ & & 15 & $9-17$ & \\
\hline $18-19$ & 211 & 18.4 & $138(65.4)$ & $73(34.6)$ & & 16 & $9-18$ & \\
\hline \multicolumn{9}{|c|}{ Economic class } \\
\hline A & 47 & 4.6 & $30(63.8)$ & $17(36.2)$ & 0.09 & 15 & 10-18 & $0.30 * \star \star$ \\
\hline B & 443 & 43.0 & $224(50.3)$ & $221(49.7)$ & & 15 & 10-18 & \\
\hline C & 486 & 47.2 & $230(47.2)$ & $257(52.8)$ & & 15 & $9-20$ & \\
\hline $\mathrm{D}$ & 54 & 5.2 & $22(40.7)$ & $32(59.3)$ & & 14.5 & $13-18$ & \\
\hline
\end{tabular}

* Chi-square;

** Mann-Whitney;

$\star \star \star *$ Kruskall-Wallis. 
Figure 1

Distribution of teenagers according to general indicator of HIV/AIDS-related knowledge. Vespasiano, Minas Gerais State, Brazil, 2010

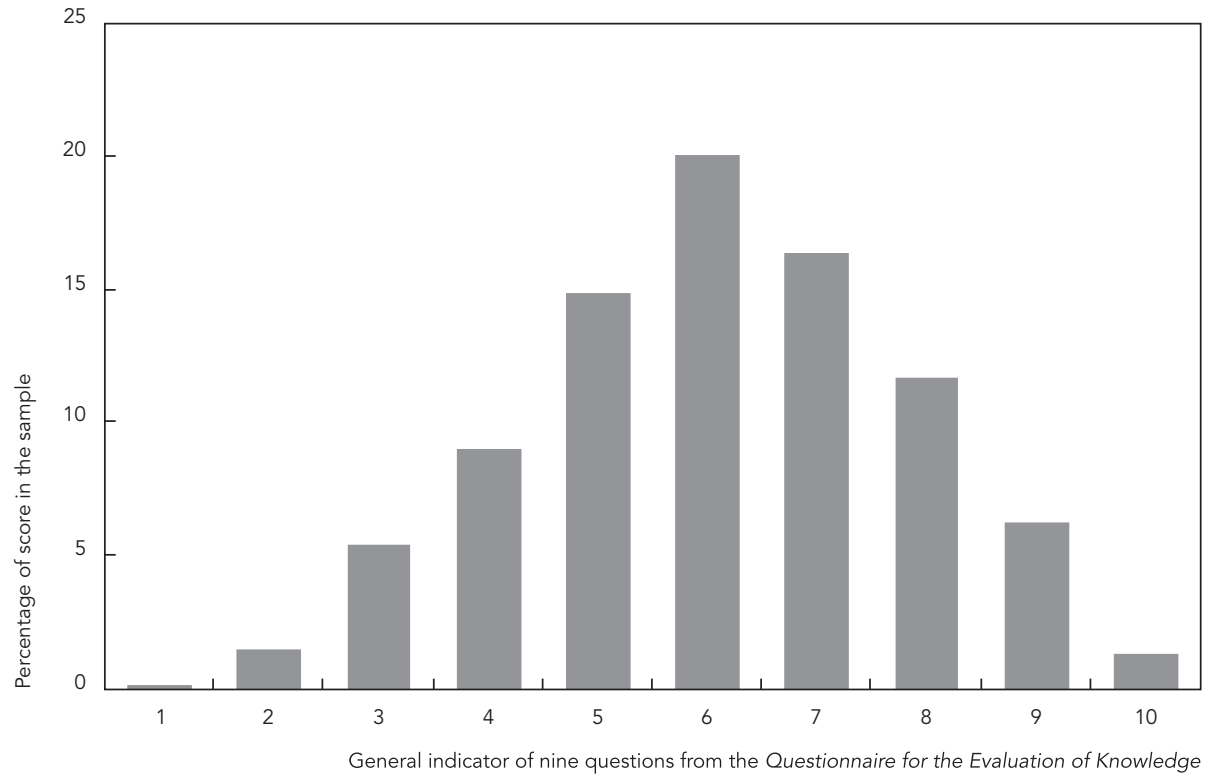

Table 2

Condom use during first sexual intercourse and in the previous six months according to gender, grade in school, age, and economic class among a sample of teenagers in Vespasiano, Minas Gerais State, Brazil, 2010.

\begin{tabular}{|c|c|c|c|c|c|c|c|}
\hline \multirow[t]{2}{*}{ Variables } & \multicolumn{3}{|c|}{ Used condoms during first sexual intercourse? } & \multicolumn{4}{|c|}{ Condom use in previous 6 months } \\
\hline & $\begin{array}{c}\text { Yes } \\
\text { n (\%) }\end{array}$ & $\begin{array}{c}\text { No } \\
\text { n (\%) }\end{array}$ & $\mathrm{p}$-value * & $\begin{array}{c}\text { Rarely or never/ } \\
\text { Less than half } \mathrm{n}(\%)\end{array}$ & $\begin{array}{l}\text { Half/More than half } \\
\text { n (\%) }\end{array}$ & $\begin{array}{l}\text { Always } \\
\text { n (\%) }\end{array}$ & $\mathrm{p}$-value * \\
\hline Gender & & & & & & & $<0.001$ \\
\hline Male & $200(67.1)$ & $98(32.9)$ & 0.25 & $58(20.6)$ & $49(17.4)$ & $175(62.0)$ & \\
\hline Female & $191(71.8)$ & $75(28.2)$ & & $79(30.5)$ & $72(27.8)$ & $108(41.7)$ & \\
\hline \multicolumn{8}{|l|}{ Grade } \\
\hline 1 st & $139(68.8)$ & $63(31.2)$ & 0.80 & $54(27.8)$ & $37(19.1)$ & $103(53.1)$ & 0.56 \\
\hline $2^{\text {nd }}$ & $131(68.6)$ & $60(31.4)$ & & $45(25.1)$ & $41(22.9)$ & $93(52.0)$ & \\
\hline 3 rd & $123(71.1)$ & $50(28.9)$ & & $38(22.4)$ & $44(25.9)$ & $88(51.7)$ & \\
\hline \multicolumn{8}{|c|}{ Age (years) } \\
\hline $14-15$ & $59(76.6)$ & $18(23.4)$ & 0.36 & $13(17.6)$ & $13(17.6)$ & $48(64.8)$ & 0.04 \\
\hline $16-17$ & $233(68.1)$ & 109(31.9) & & 78 (23.9) & 77 (23.6) & $171(52.5)$ & \\
\hline $18-19$ & $97(69.3)$ & 43 (30.7) & & 45 (33.1) & $31(22.8)$ & $60(44.1)$ & \\
\hline \multicolumn{8}{|c|}{ Economic class } \\
\hline$A$ & $24(80)$ & $6(20.0)$ & 0.12 & $4(13.8)$ & $6(20.7)$ & 19 (65.5) & 0.11 \\
\hline B & $146(64.6)$ & $80(35.4)$ & & 65 (30.5) & 39 (18.3) & 109 (51.2) & \\
\hline C & $166(73.1)$ & 61 (26.9) & & $50(22.7)$ & $58(26.4)$ & $112(50.9)$ & \\
\hline $\mathrm{D}$ & $16(72.7)$ & $6(27.3)$ & & $3(13.6)$ & $6(27.3)$ & $13(59.1)$ & \\
\hline
\end{tabular}

* Chi-square statistical test. 
and in subsequent sexual relations, an association between these variables was submitted to the chi-square test. There was a statistically significant association between condom use at first sexual intercourse and higher frequency of condom use in the six months prior to the study $\left(\chi^{2}=87.2 ; \mathrm{p}<0.001\right)$. Likewise, individuals that had not used condoms during their first sexual intercourse were more likely not to have used them in the last six months (Table 3).

Correlations were tested between indicators of high-risk sexual behavior (lack of condom use and multiple sexual partners) and the General Indicator of Knowledge on HIV/AIDS. High-risk sexual behavior and knowledge on HIV/AIDS were not correlated. That is, knowledge did not influence the adoption of safe sex behavior (Table 4).

\section{Discussion}

The results on teenagers' knowledge related to HIV/AIDS indicate that individuals had doubts concerning the questions presented to them. Most of the teenagers were unable to answer four of the nine questions. The results were not consistent with those found in the PCAP 2008 survey 11 , which showed high rates of knowledge on forms of HIV infection and AIDS prevention among young people. Considering also that HIV/ AIDS prevention involves an interrelated set of knowledge and information, a comprehensive understanding of the subject is important. Doubts on forms of transmission of the virus may become an element of vulnerability for the young person.

Compared to recent studies, teenagers in Vespasiano also showed lower rates of knowledge. In Canoas, Rio Grande do Sul State, in southern Brazil, knowledge on AIDS was adequate for the majority of the questions $(91 \%$ of the teenagers knew what the disease is and $89.6 \%$ knew it is caused by a virus) 25 . In the city of Rio de Janeiro, in a study with a sample of 945 teenagers from public and private schools, all the young people interviewed knew about AIDS and its forms of transmission 21.

The results in Vespasiano corroborate findings from other studies on sexual behavior: teenagers' sexual initiation is increasingly earlier, especially for boys 26 . In parallel, various studies in the national and international literature identify a higher rate of unprotected sexual initiation

Table 3

Kendall correlation between measures of risk behavior and general indicator of HIV/AIDS knowledge among a sample of teenagers in Vespasiano, Minas Gerais State, Brazil, 2010.

\begin{tabular}{lc}
\hline Variable & General indicator of HIV/AIDS knowledge \\
\hline Condom use during first sexual intercourse & -0.03 \\
Condom use in previous six months & 0.01 \\
Number of sexual partners in previous year & 0.02 \\
\hline
\end{tabular}

Note: none of the correlations reached statistical significance at $\alpha=0.05$.

\section{Table 4}

Association between condom use during first sexual intercourse and in the previous six months among a sample of teenagers in Vespasiano, Minas Gerais State, Brazil, 2010

\begin{tabular}{lcccc}
\hline Variables & \multicolumn{3}{c}{ Condom use during first sexual intercourse } \\
& Yes & No & Total & p-value * \\
& $\mathbf{n}(\%)$ & $\mathbf{n}(\%)$ & \\
\hline $\begin{array}{l}\text { Condom use in previous 6 months } \\
\text { Rarely/Less than half }\end{array}$ & $56(41.2)$ & $80(58.8)$ & 136 & 122 \\
Half/More than half & $84(68.9)$ & $38(31.1)$ & 283 \\
Always & $242(85.5)$ & $41(14.5)$ & 541 \\
Total & $382(70.6)$ & $159(29.4)$ & \\
\hline
\end{tabular}

* Chi-square statistical test. 
among teens with early initiation, although other studies show conflicting results $27,28,29$. In the current study, although boys began sexual practice earlier than girls, they showed higher adherence to condom use in their sexual relations in the previous six months. However, despite the differences in age at sexual initiation, girls and boys did not show significant differences in condom use during their first sexual intercourse.

The difference in mean age at first sexual intercourse in Vespasiano corroborates findings from elsewhere in Brazil 26,28,30,31. According to an international study 32 , these differences are greater in less developed countries,, with earlier sexual initiation in boys. The same study indicates that countries such as France and England have shown a reduction in this difference between the sexes. Even with the evidence that early sexual initiation is associated with high-risk behavior, regardless of whether sexual initiation is early or late, it should be accompanied by well-structured and mature personal definitions that foster a conscientious and healthy choice of prevention strategies.

Studies by Kirby 33,34 have shown that programs that only encourage postponing sexual initiation are ineffective. The same studies further indicate that educational approaches to condom use fail to encourage frequent use or discuss age at sexual initiation. More important than encouraging young people to postpone sexual relations is to provide the means for subjects that opt to become sexually active to do so with responsibility and protection. The Brazilian National Program for STD/AIDS, currently one of the main agencies responsible for initiatives in AIDS prevention in the country, does not consider the postponement of sexual initiation as a relevant component of its policy 29,31,35.

The results further suggest that knowledge acquired on STDs and forms for their prevention are more effective when the individuals have still not established bonds of trust with their partners and when sexual practices are a new fact. This may explain younger teenagers' better adherence to condom use and the positive association between condom use at first sexual intercourse and in subsequent relations. These results highlight the significance of first sexual intercourse and the importance of elaborating on HIV/AIDS information and perception before sexual practices begin.

Meanwhile, low adherence to condom use in the previous six months indicates that related awareness-raising activities should be continued throughout adolescence. Such discussions should focus on both the early and later years of adolescence, using approaches to raise individ- ual awareness on the risk of unprotected sexual practices, regardless of the type of relationship with the partner.

In this sense, a high proportion of teenagers, especially girls, failed to use condoms in their sexual relations in the previous six months. According to a study in São Paulo, $65.5 \%$ of teenagers did not consider themselves at risk of acquiring HIV/ AIDS, and of these, $23.8 \%$ believed this because that had only one sexual partner, in whom they trusted ${ }^{36}$. As in the adult population, teenagers display significant differences in their patterns of condom use according to the type of relationship with the partner - whether defined as casual or stable $30,37,38,39$. The unpredictability of sexual relations, lack of condoms, and subordination to the sexual partner are reasons frequently cited by young people for unprotected sexual practices 40 .

Studies further indicate that condom use is determined not only by individual factors, but also by socio-cultural ones $30,31,39$. One's grade in school, age, gender, and socioeconomic status can have a direct influence on adherence to the method. For example, schooling is an important differential for condom use in the Brazilian population 11,37,41; the more years of schooling, the higher the rate of condom use. However, in Vespasiano schooling and economic class were not statistically associated with condom use. In the current study, the sample may have been too economically and educationally homogeneous to reveal differences between classes. Studies evaluating populations of teenagers with wider socioeconomic differences are thus necessary.

According to the last national survey on the Brazilian population's sexual behavior and perceptions concerning HIV/AIDS, young people used condoms more than other age brackets 11 . According to this same study, young people also had the greatest access to free condoms, and schools were the second leading place for acquiring them. The study also showed that approximately 50,214 of Brazil's schools were participating in the School Health and Prevention Program of the Ministry of Health. The Program develops strategies to reduce the vulnerability of teenagers and young people, and the activities are conducted jointly between schools and primary healthcare centers. The promotion of healthy behaviors requires participatory work methodologies that not only make condoms available, but raise young people's awareness concerning the importance of prevention, while integrating schools and health services.

Scientific knowledge on HIV/AIDS was not significantly associated with safe sexual behavior in this study, as shown by rates of condom use and number of sexual partners. Thus, the best in- 
formed teenagers were not necessarily those that displayed safe behaviors. Meanwhile, younger individuals showed a higher tendency towards safe practices. Certainly, and corroborating other authors' findings $22,25,42,43,44$, there are questions that extrapolate scientific knowledge on HIV/AIDS, including those of a social and cultural order, transmitted and maintained by groups, highly representative during adolescence. Thus, despite the importance of the young person's scientific knowledge, it is not possible to overlook the cultural influences permeating the life context and behaviors of these individuals.

Scientific evidence confirms the above. According to a study in secondary schools in Rio de Janeiro, $94 \%$ of teenagers emphasized the need for condom use and proved to be well-informed on most of the questions on STD prevention, but only $34 \%$ reported using condoms in their sexual relations 21 . The Brazilian and international literature shows similar findings 36,45 . Other studies report that among methods to prevent HIV/ AIDS, male condoms are the method most frequently cited by teenagers 46,47 . Nevertheless, many teenagers fail to use them because they dislike the method or because they trust their sexual partners 48 .

Disease prevention and health promotion in the life world of teenagers begins with the understanding of individual conceptions and valorization of different realities (economic, social, age-based, and gender-based) experienced by teenagers. The challenges are definitely greater considering that the success of actions requires commitment by the teenagers' social universe: family, friends, media, school, and health services. Studies have helped to show that in order to work with education among teenagers, it is essential to recognize that they detain knowledge and practices that should be valued in the knowledge-building process. Engaging teenagers (that is, making them protagonists that understand and consciously direct their sexual and affective history) favors the success of health actions.

Knowledge on HIV is not sufficient to induce preventive behaviors, and the gap in such knowledge needs to be dealt with. In order to engage teenagers, to help them grasp knowledge and promote the necessary changes in their behavior, health professionals are key partners. This scenario highlights the importance of group work combined with a keen ear for comprehensive action. Collaboration between health and education is a strategy that should be reinforced.
Schools work with information and knowledge, and the gaps, lapses, and subjectivity can be prioritized in the follow-up by health services.

The lack of data on situations of violence, alcohol and drug use, and school absenteeism by teenagers are limitations to the current study. Qualitative studies are also important for a more in-depth interpretation of incongruent behaviors that characterized the teenagers in this study.

\section{Conclusion}

The existence of socially transmitted and constructed conceptions and beliefs may determine the existing gaps between knowledge on HIV/ AIDS and the practices reported by teenagers. In the current study, well-informed individuals on questions involving forms of transmission and risk situations for HIV/AIDS did not necessarily adopt safe sexual behaviors. Difficulty exists in recognizing the risk related to unprotected practices, especially in relation to condom use and knowing and trusting the sexual partner.

Even with the scientific advances 20 years into the epidemic, HIV/AIDS-related conceptions, including among teenagers, fall short of incorporating a grasp of the terms "risk behaviors" and "vulnerability". In the current study, social and subjective issues appear to have exerted a greater influence on individual behavior than acquired knowledge. The forms of grasping knowledge and its impact on teenagers' sexual behavior need to be better empowered and elaborated in the sphere of health and education. Despite some isolated initiatives by schools and health services, the municipality of Vespasiano lacks actions that prioritize integration between schools and health services. In addition to this collaboration, an approach to the world of meanings that permeates adolescence should favor the development of more effective health promotion strategies.

\section{$\underline{\text { Implications and contributions }}$}

The contribution of this study was to investigate the gaps between knowledge on questions involving HIV transmission and the adoption of safe and responsible sexual behavior. Understanding the world of meanings permeating teenagers' actions and sexual practices should favor the elaboration of health strategies that resonate with these young individuals. 


\section{Resumen}

El objetivo fue investigar las lagunas entre el conocimiento sobre el VIH/SIDA y el comportamiento sexual en adolescentes de enseñanza media. Delineación transversal con muestra representativa y aleatoria de 1.158 adolescentes entre 14 a 19 años, matriculados en nueve escuelas públicas que respondieron a cuestionarios validados. El análisis de los datos implicó estadística descriptiva y tests de hipótesis (chi-cuadrado, Mann-Whitney y Kruskal-Wallis, Kendal y test exacto de Fisher). La mayoría de los adolescentes (98,7\%) presentó dudas en alguna cuestión propuesta. El uso del preservativo en la primera relación sexual influenció el uso en las relaciones de los últimos seis meses. No hubo asociación estadística entre el conocimiento sobre VIHISIDA con la frecuencia del uso de preservativo y la multiplicidad de compañeros sexuales. Es necesaria la implementación de acciones en salud que articulen la escuela a los servicios de salud y que además de trabajar con la información, valoren la individualidad de los adolescentes en la construcción de las propuestas.

VIH; Sindrome de Inmunodeficiencia Adquirida; Adolescente; Conocimientos, Actitudes y Práctica en Salud; Conducta Sexual

\section{Contributors}

L. R. Moura contributed to the study's conceptualization and project, data analysis and interpretation, writing of the article, and approval of the final version for publication. J. R. Lamounier, P. R. Guimarães, J. M. Duarte, M. T. C. Beling, J. A. Pinto, and E. M. A. Goulart collaborated in the data analysis and interpretation, critical revision of the intellectual content, and approval of the final version for publication. C. F. C. Grillo participated in the study conceptualization and project, data analysis and interpretation, writing of the article, critical revision of the intellectual content, and approval of the final version for publication.

\section{Acknowledgements}

The authors wish to thank Ricardo José de Moura and Prof. Alisson Araújo, the School of Health and Human Ecology/Vespasiano, the STD/AIDS Program of Vespasiano, Capes, and FAPEMIG.

\section{References}

1. Camargo BV, Botelho LJ. AIDS, sexuality and attitude of adolescents about protection against HIV Rev Saúde Pública 2007; 41:61-82.

2. Hearst N, Chen S. Condom promotion for AIDS prevention in the developing world: is it working? Stud Fam Plann 2004; 35:39-47.

3. Kaestle CE, Halpern CT, Miller WC, Ford CA. Young age at first sexual intercourse and sexually transmitted infections in adolescents and young adults Am J Epidemiol 2005; 161:774-80.

4. Shrier LA. Sexually transmitted diseases in adolescents: biologic, cognitive, psychological, behavioral, and social issues. Adolesc Med Clin 2004 15:215-34.

5. Tamayo A, Lima A, Marques J, Martins L. Prioridades axiológicas e uso de preservativo. Psicol Reflex Crít 2001; 14:167-75.
6. Lanfranchi JB, Touzard H. Étude d'un modèle de la motivation à se protéger contre le sida. Cahier Internationaux de Psychologie Sociale 2000; (4748):110-48

7. Camargo BV, Barbará A. Efeitos de panfletos informativos sobre a AIDS em adolescentes. Psicol Teor Pesqui 2004; 20:279-87.

8. Ferreira MP. Nível de conhecimento e percepção de risco da população brasileira sobre o HIV/Aids, 1998 e 2005. Rev Saúde Pública 2008; 42 Suppl 1:S65-71.

9. Camargo BV, Bertoldo RB. Comparação da vulnerabilidade de estudantes da escola pública e particular em relação ao HIV. Estud Psicol (Campinas) 2006; 23:369-79. 
10. Ayres JR, Freitas AC, Santos MAS, França JI, Saletti HCF. Adolescência e AIDS: avaliação de uma experiência de educação preventiva entre pares. Interface Comun Saúde Educ 2003; 7:123-38.

11. Departamento de DST, Aids e Hepatites Virais, Secretaria de Vigilância em Saúde, Ministério da Saúde. Pesquisa de conhecimentos atitudes e praticas da população brasileira. http://www.aids.gov. br/publicacao/pcap-2008 (accessed on 20/Nov/ 2010).

12. Paiva V. Sexualidade e gênero num trabalho com adolescentes para prevenção do HIV/Aids. In: Parker R, Bastos C, Galvão J, Pedrosa JS, organizadores. A AIDS no Brasil (1982-1992). Rio de Janeiro: Associação Brasileira Interdisciplinar de AIDS/Instituto de Medicina Social, Universidade do Estado do Rio de Janeiro/Editora Relume-Dumará; 1994. p. 231-50.

13. Bastos FI, Coutinho K. Tão longe, tão perto: as pesquisas sobre HIV/AIDS no Brasil. In: Parker R, Galvão J, Bessa MS, organizadores. Saúde, desenvolvimento e política: respostas frente a AIDS no Brasil. Rio de Janeiro: Associação Brasileira Interdisciplinar de AIDS/São Paulo: Editora 34; 1999. p. 339-95.

14. Ministério da Saúde. Boletim epidemiológico AIDS 2002; ano XVI, n. 1. http://www.aids.gov.br/bole tim_epidemiologico/bol_dezembro_2002/bole tim.asp (accessed on 28/Mar/2006).

15. Centro Brasileiro de Análise e Planejamento, Ministério da Saúde. Relatório final de pesquisa sobre o comportamento sexual da população brasileira e percepções sobre o HIV/AIDS. Brasília: Ministério da Saúde; 1999.

16. Lemeshow S, Hosmer D. Adequacy of sample size in health studies. Chichester: John Wiley; 1990.

17. Berquó ES, editor. Comportamento sexual da população brasileira e percepções do HIV/AIDS. Brasília: Ministério da Saúde; 2000.

18. Almeida MCC, Aquino EMC, Gaffikin L, Magnani RJ. Uso de contracepção por adolescentes de escolas públicas na Bahia. Rev Saúde Pública 2003; 37:566-75.

19. Façanha MC, Menezes BLF, Fontenele ADB, Melo MA, Pinheiro AS, Carvalho CS, et al. Conhecimento sobre reprodução e sexo seguro de adolescentes de uma escola de ensino médio e fundamental de Fortaleza - Ceará. DST J Bras Doenças Sex Transm 2004; 16: 5-9.

20. Cunha CF, Cadete MMM, Ferreira RA, Guimarães PR, Miranda SM. Saúde do adolescente. Belo Horizonte: Núcleo de Educação em Saúde Coletiva, Universidade Federal de Minas Gerais; 2012.

21. Trajman A, Belo MT, Teixeira EG, Dantas VCS, Salomão FM, Ledo AJ. Conhecimento sobre DST/AIDS e comportamento sexual entre estudantes do ensino médio no Rio de Janeiro, Brasil. Cad Saúde Pública 2003; 19:127-33.

22. Antunes MC, Peres CA, Paiva V, Stall R, Hearst N. Diferenças na prevenção da AIDS entre homens e mulheres jovens de escolas públicas em Säo Paulo, SP. Rev Saúde Pública 2002; 36(4 Suppl):88-95.

23. Barone C, Ickovics JR, Ayres TS, Katz SM, Voyce CK, Weissberg RP. High-risk sexual behavior among young urban students. Fam Plann Perspect 1996; 28:69-74.
24. Warren CW, Santelli JS, Everett SA, Kann L, Collins JL, Cassell C, et al. Sexual behavior among U.S. high school students, 1990-1995. Fam Plann Perspect 1998; 30:170-2.

25. Nader SS, Gerhardt CR, Hartmann-Nader PJ, Pereira DN. Juventude e AIDS: conhecimento entre os adolescentes de uma escola pública em Canoas, RS. Revista da AMRIGS 2009; 53:374-81.

26. Paiva V, Calazans G, Venturi G, Dias R. Idade e uso de preservativo na iniciação sexual de adolescentes brasileiros. Rev Saúde Pública 2008; 42 Suppl 1:45-53.

27. Svare EI, Kjaer SK, Thomsen BL, Bock JE. Determinants for non-use of contraception at first in tercourse: a study of 10,841 young Danish women from the general population. Contraception 2002; 66:345-50.

28. Teixeira AMFB, Knauth DR, Fachel JMG, Leal AF. Adolescentes e uso de preservativos: as escolhas de jovens de três capitais brasileiras na iniciação e na última relação sexual. Cad Saúde Pública 2006; 22:1385-96.

29. Narring F, Wydler H, Michaud PA. First sexual intercourse and contraception: a cross-sectional survey on the sexuality of 16-20-year-olds in Switzerland. Schweiz Med Wochenschr 2000; 130:1389-98.

30. Borges ALV, Schor N. Início da vida sexual na adolescência e relações de gênero: um estudo transversal em São Paulo, Brasil, 2002. Cad Saúde Pública $2005 ; 21: 499-507$

31. Calazans G. Os jovens falam sobre sua sexualidade e saúde reprodutiva: elementos para reflexão. In: Abramo HW, Branco PM, organizadores. Retratos da juventude brasileira: análise de uma pesquisa nacional. São Paulo: Editora Fundação Perseu Abramo/Instituto Cidadania; 2005. p. 215-41.

32. Wellings K, Collumbien M, Slaymaker E, Singh S, Hodges Z, Patel D, et al. Sexual behaviour in context: a global perspective. Lancet 2006; 368 : 1706-28.

33. Kirby D. Emerging answers: research findings on programs to reduce teen pregnancy, 2002. https:// www.teenpregnancy.org/resources/data/pdf/ab stinence_eval.pdf (accessed on 02/Dec/2010).

34. Kirby D. Emerging answers 2007. Research findings on programs to reduce teen pregnancy and sexually transmitted diseases. http://www.popline. org/ docs/322584 (accessed on 03/Dec/2010).

35. Paiva V. Fazendo arte com camisinha: sexualidades jovens em tempos de AIDS. São Paulo: Summus; 2000.

36. Doreto DT, Vieira EM. O conhecimento sobre doenças sexualmente transmissíveis entre adolescentes de baixa renda em Ribeirão Preto, São Paulo, Brasil. Cad Saúde Pública 2007; 23:2511-6.

37. Lagarde E, Caraël M, Glynn JR, Kanhonou L, Abega SC, Kahindo M, et al. Educational level is associated with condom use within non-spousal partnerships in four cities of sub-Saharan Africa. AIDS 2001; 15:1399-408.

38. Holtzman D, Bland S, Lansky A, Mack KA. HIVrelated behaviors and perceptions among adults in 25 states: 1997 Behavioral Risk Factors Surveillance System. Am J Public Health 2001; 91:1882-8. 
39. Jenkins RA, Manopaiboon C, Samuel AP, Jeeyapan S, Carey JW, Kilmarx PH, et al. Condom use among vocational school students in Chiang Raí, Thailand. AIDS Educ Prev 2002; 14:228-45.

40. Almeida MCC, Aquino EML, Gaffikin L, Magnani RJ. Uso de contracepção por adolescentes de escolas públicas na Bahia. Rev Saúde Pública 2003; 37:566-75.

41. Heilborn ML, Aquino EML, Bozon M, Knauth DR, organizadores. O aprendizado da sexualidade: reprodução e trajetórias sociais de jovens brasileiros. Rio de Janeiro: Editora Garamond; 2006.

42. Moisés JS, Bueno SMV. A compreensão sobre sexualidade e sexo nas escolas segundo professores do ensino fundamental. Rev Esc Enferm USP 2010 44:205-12.

43. Camargo EAI, Ferrari RAP. Adolescentes: conhecimentos sobre sexualidade antes e após a participação em oficinas de prevenção. Ciênc Saúde Coletiva 2009; 14:937-46.

44. Sociedade Civil Bem-Estar Familiar no Brasil. Adolescentes, jovens e a pesquisa nacional sobre demografia e saúde: um estudo sobre fecundidade, comportamento sexual e saúde reprodutiva. Rio de Janeiro: Fundo das Nações Unidas para à Infância/Centers for Disease Control and Prevention; 1999 .
45. Diclemente RJ, Zorn J, Temoshok L. Adolescent and AIDS: survey of knowledge, attitudes and beliefs about AIDS in San Francisco. Am J Public Health 1986; 76:1443-5.

46. Martins LBM. Conhecimento, atitude e prática sobre métodos anticoncepcionais, prevenção de DST/AIDS em adolescentes de escolas públicas e privadas do município de São Paulo [Dissertação de Mestrado]. Campinas: Faculdade de Ciências Médicas, Universidade Estadual de Campinas; 2005.

47. Pirotta KC, Schor N. Intenções reprodutivas e práticas de regulação da fecundidade entre universitários. Rev Saúde Pública 2004; 38:495-502.

48. Vilelas-Janeiro JMS. Educar sexualmente os adolescentes: uma finalidade da família e da escola? Rev Gaúch Enferm 2008; 29:382-90.

Submitted on 25/Aug/2012

Final version resubmitted on 16/Nov/2012 Approved on 03/Dec/2012 